\title{
L-Arginine Supplementation Alters Maternal Blood Biochemical Attributes and Milk Composition Relative to Neonatal Traits of Najdi Ewes
}

\author{
Moustafa M. Zeitoun 1,2*, Ahmed A. Al-Ghoneim³, Khalid A. Al-Sobayil1, Yasser R. Hassanein4, \\ Mohamed M. Mansour ${ }^{5}$, Kheir El-Din M. El-Azrak², Marwa F. A. Attia ${ }^{2}$, Tariq I. Almundarij ${ }^{6}$ \\ ${ }^{1}$ Department of Animal Production and Breeding, College of Agriculture and Veterinary Medicine, Qassim University, \\ Buriedah, KSA \\ ${ }^{2}$ Department of Animal and Fish Production, Faculty of Agriculture, Alexandria University, El-Shatby, Egypt \\ ${ }^{3}$ Ministry of Agriculture, Riyadh, KSA \\ ${ }^{4}$ Department of Hematology, College of Applied Medical Sciences, Qassim University, Buriedah, KSA \\ ${ }^{5}$ Department of Animal Production, Faculty of Agriculture, Damanhur University, Damanhur, Egypt \\ ${ }^{6}$ Department of Veterinary Medicine, College of Agriculture and Veterinary Medicine, Qassim University, Buriedah, KSA \\ Email: *mmzeitoun@yahoo.com
}

How to cite this paper: Zeitoun, M.M., Al-Ghoneim, A.A., Al-Sobayil, K.A., Hassanein, Y.R., Mansour, M.M., El-Azrak, K.E.-D.M., Attia, M.F.A. and Almundarij, T.I. (2019) L-Arginine Supplementation Alters Maternal Blood Biochemical Attributes and Milk Composition Relative to Neonatal Traits of Najdi Ewes. Open Journal of Animal Sciences, 9, 341-354. https://doi.org/10.4236/ojas.2019.93028

Received: April 11, 2019

Accepted: July 27, 2019

Published: July 30, 2019

Copyright () 2019 by author(s) and Scientific Research Publishing Inc. This work is licensed under the Creative Commons Attribution International License (CC BY 4.0).

http://creativecommons.org/licenses/by/4.0/

(c) (i) Open Access

\begin{abstract}
In a $2 \times 3$ factorial arrangement, 3 levels of L-arginine $(0,75$ and $150 \mathrm{mg} / \mathrm{kg}$ BW per day) were tested at two stages of pregnancy (Early 60 days vs. Late 60 days) on the maternal blood metabolites and postnatal milk composition relative to the newborn traits of Najdi ewes.. Thirty adult pregnant Najdi ewes were randomly assigned into 6 treatments $(n=5)$. Control early (CE) ewes were orally administered $50 \mathrm{~mL}$ normal saline $(0.9 \% \mathrm{NaCl})$ daily during the first 60 days of pregnancy; control late (CL) ewes were similar to CE except saline was given at the last 60 days of pregnancy; low dose of L-arginine at early pregnancy (LE); low dose of L-arginine at late pregnancy (LL); high dose of L-arginine at early (HE) and high dose of L-arginine at late pregnancy (HL). Blood and milk samples were collected on a weekly basis. Data of lambing and newborn traits were considered. There were non-significant differences in litter size due to L-arginine; however lamb birth and weaning weights increased by $35 \%$ in LE-ewes. Arginine did not change blood protein and albumin. Low arginine decreased lipid fractions, creatinine, urea, and milk fat; however, it increased AST, ALT, milk lactose and milk ash. Administration of L-arginine at $75 \mathrm{mg} / \mathrm{Kg} \mathrm{BW}$ per day for 60 days at an early gestation in ewes improved the maternal body health and milk composition for the welfare of the neonates.
\end{abstract}




\section{Keywords}

L-Arginine, Ewes, Fetus, Metabolites, Lactation, Offspring

\section{Introduction}

Najdi ewes represent a valuable sheep population in the Kingdom of Saudi Arabia. However, these animals are bred under hot climates, sandstorms, lack of fresh water and scarcity of green forages resulting in reduced productivity and profitability. Several studies have been focusing on the roles of essential and nonessential amino acids on animal growth, development, reproduction, production, and health wellbeing aspects [1]. L-arginine is considered a nutritionally semi-essential amino acid in case of gestating mammals [2]. It has been found that dietary supplementation or intravenous administration of L-arginine is effective in improving functions of reproduction, cardio vascularity, pulmonary system, renal filtration, gastrointestinal, liver, and immunity, as well as facilitating wound healing, enhancing insulin sensitivity and maintaining tissue integrity [3]. Dietary supplementation of L-arginine increased nitric oxide (NO) synthesis in various tissues within physiological ranges [4]. NO is considered an endothelium-derived relaxing factor essential for increasing systemic vasodilatation [5] [6]. Also, $\mathrm{NO}$ is essential to placental growth and angiogenesis (the growth of new vessels from the existing vasculature) and therefore, for increasing uterine and placental-fetal blood flow [7]. Moreover, arginine was found to enhance embryonic implantation and development in rats [8], sheep [9] and pigs [10]. It has been recently reported that supplementing pregnant ewes with a low dosage of L-arginine at the early stage of gestation increased lamb birth weight and survival, and improved maternal health [11]. However, little studies have been conducted to relate the maternal health and neonatal traits with subsequent milk composition in ewes given L-arginine during gestation. Therefore, the aim of the present study was to investigate the effects of oral administration of L-arginine during two stages of pregnancy on the maternal and neonatal health wellbeing, and subsequent milk composition in Najdi ewes.

\section{Materials and Methods}

\subsection{Animals and Location}

This study has been conducted during September 2017 and June 2018. Pregnant Najdi ewes at their first to third parity with age of 12 - 30 month and weight of 40 - $60 \mathrm{~kg}$ (average $51.4 \pm 8.7 \mathrm{~kg}$ ) were reared in the same breeding farm, tested to be free from mandatory reportable diseases and located in animal production research unit, Agricultural experimental station, Qassim University, Kingdom of Saudi Arabia. Ewes were maintained in semi shaded pens, offered $300 \mathrm{~g}$ barley/head/day as a concentrate in addition to alfalfa hay ad lib according to NRC requirements [12]. This diet contains $60 \% \mathrm{TDN}, 2.2 \mathrm{Mcal} / \mathrm{Kg} \mathrm{ME}$ and 13\% crude 
proteins. Mineral-balanced mixture blocks and clean drinking water were offered as free choice. An approval of the Qassim University animal rights, ethics and use was confirmed.

\subsection{Experimental Design}

Thirty adult pregnant Najdi ewes were randomly assigned into six groups ( $\mathrm{n}=5$ ewes/group) as follow; first group (CE) was defined as control early pregnancy in which ewes were at their early (first 60 days post breeding) stage of pregnancy and given orally daily $50 \mathrm{ml}$ normal saline $(0.9 \% \mathrm{NaCl})$, second group (CL) ewes were in late (last 60 days) pregnancy stage and orally administered $50 \mathrm{ml}$ normal saline daily until parturition, third group (LE) ewes were given daily low dose of L-arginine [Herbstore, Diamond Bar, CA USA ( $75 \mathrm{mg} / \mathrm{kg} \mathrm{B.W/day)]} \mathrm{during} \mathrm{the}$ first 60 days of pregnancy, group four (LL) ewes were given daily similar dose of group 3 during their last 60 days of gestation, group five (HE) ewes were given daily high dose of L-arginine ( $150 \mathrm{mg} / \mathrm{kg} \mathrm{B.W} /$ day) during the early 60 days of pregnancy and group six (HL) ewes were given similar dose to group five during their last 60 days of pregnancy.

\subsection{Blood and Milk Sampling and Analyses}

Blood samples for plasma were collected via the jugular vein in heparinized Vacutainer $^{\circledR}$ tubes (Becton Dickinson, Oxford, UK). Sampling just started before the commencement of the treatment $(\mathrm{d}=0)$ and proceeded once per a week until parturition in the late pregnant groups, however in the early pregnant ewes, blood samples were collected once per a week during treatment period and proceeded in a once per month thereafter until parturition. Plasma was separated immediately after blood collection by centrifugation $\left(1500 \times \mathrm{g}\right.$ for $\left.15 \mathrm{~min} / 5^{\circ} \mathrm{C}\right)$, harvested, aliquot and stored at $-20^{\circ} \mathrm{C}$ until analysis. Blood biochemical constituents were determined by commercial reagents (Human Gesellschaft für Biochemica und Diagnostica $\mathrm{mbH}$, Germany). Total protein was determined according to Weichselbaum [13]. Albumin was determined according to Doumas et al. [14]. Globulins were mathematically calculated by the subtraction of albumin value of the total protein value. Cholesterol and Triglycerides were determined according to Seftel et al. [15]. LDL was determined according to Okada et al. [16]. HDL was determined according to Gordon et al. [17]. Creatinine was determined according to Bartels and Boehmer [18]. Urea was determined according to Fawcett and Scott [19]. Aspartate aminotransferase and alanine aminotransferase were determined according to Thefeld et al. [20].

Milk samples were collected in clean tubes containing potassium dichromate $(0.1 \mathrm{ml}, 0.3 \%)$. Sampling started soon after the end of colostrum and once per a week until weaning at two months of neonate age. Milk samples were kept in the fridge $\left(5^{\circ} \mathrm{C}\right)$ until proximate analysis was performed. Milk samples were analyzed using FUNK GERBER (Lactostar, Germany) milk analyzer according to the AOAC [21]. Briefly, $30 \mu \mathrm{l}$ of each milk sample was withdrawn and percen- 
tage of milk fat, protein, total solids, solids not fat, lactose and ash were determined. A duplicate of each sample were determined to estimate the precision of the assay.

\subsection{Offspring Traits}

Offspring were weighed at birth and at weaning (day 60) using a scale balance. Also percentage of survival at birth and weaning were recorded within each treatment.

\subsection{Statistical Analysis}

All variables data were analyzed by the least square analysis of variances for repeated measures procedure of SAS [22]. Mean comparisons among treatments were achieved by the Duncan's Multiple Range Test [23]. The significance level was considered at $P<0.05$.

\section{Results}

\subsection{Lamb Traits}

As depicted in Figure 1, ewes given the low arginine during early pregnancy gave birth to the heaviest lambs $(4.99 \mathrm{~kg})$ representing about $33 \%$ increase in body weight compared to their control counterparts $(3.76 \mathrm{~kg})$. Increasing the arginine dose given at early gestation didn't exert better enhancement on neonatal birth weight (4.99 vs 4.76 for low vs high). However, giving L-arginine at late gestation was in favor of the low dose $(4.63 \mathrm{~kg})$ than the high dose $(3.76 \mathrm{~kg})$ on birth weight. The ultimate finding is that giving low dose $(75 \mathrm{mg} / \mathrm{kg} \mathrm{B.W})$ of L-arginine either at early or late gestation was beneficial to the growth of sheep

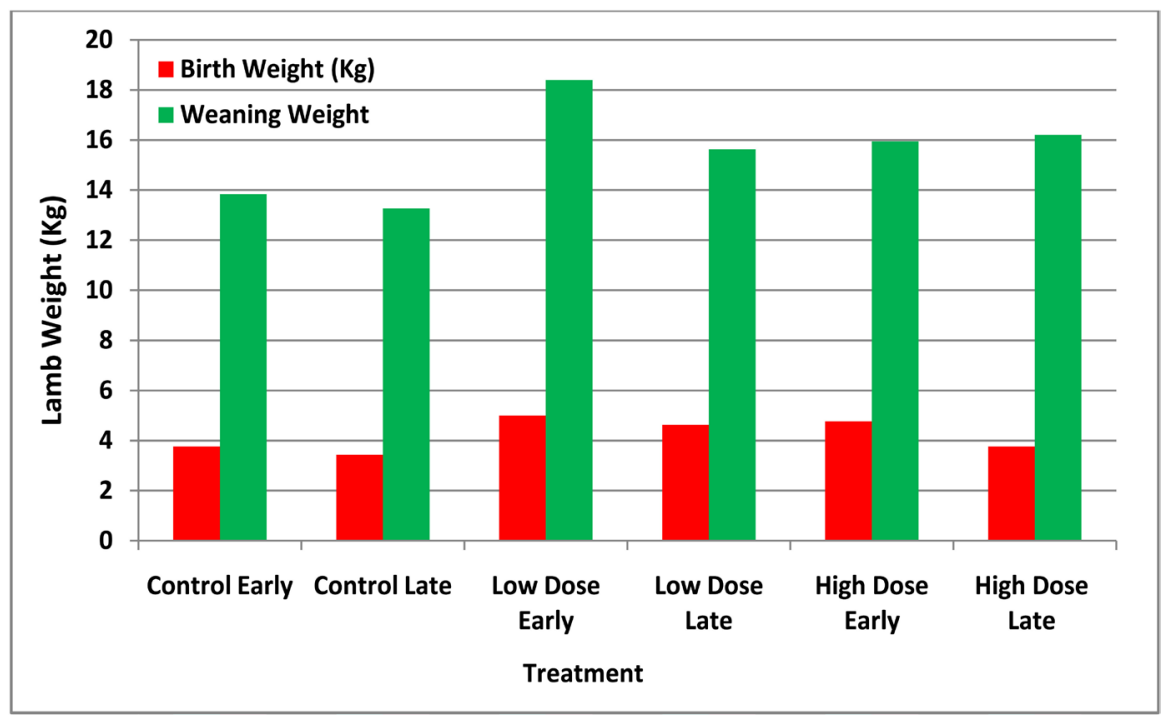

Figure 1. Effect of L-arginine dose $\times$ stage of pregnancy at which arginine was given on lamb's birth and weaning weights of Najdi ewes $(\mathrm{CE}=$ Saline at early pregnancy, $\mathrm{CL}=$ Saline at late pregnancy, $\mathrm{LE}=75 \mathrm{mg} / \mathrm{kg} \mathrm{BW}$ at early pregnancy, $\mathrm{LL}=75 \mathrm{mg} / \mathrm{kg} \mathrm{BW}$ at late pregnancy, $\mathrm{HE}=150 \mathrm{mg} / \mathrm{kg} \mathrm{BW}$ at early pregnancy, $\mathrm{HL}=150 \mathrm{mg} / \mathrm{kg}$ BW at late pregnancy). 
fetus, however giving a high dose $(150 \mathrm{mg} / \mathrm{kg} \mathrm{B.W})$ at late gestation was not as effective in this respect as when given at early gestation. The heaviest $(P<0.05)$ lamb weaning weight at 60 days age (Figure 1 ) was derived from ewes given the low dose of arginine at early pregnancy $(18.4 \mathrm{~kg})$ representing about $33 \%$ above control $(13.84 \mathrm{~kg})$ lamb's weight. No significant differences $(P>0.05)$ were found among other treatments $(15.63,15.95$ and $16.21 \mathrm{~kg}$ in LL, HE and HL, respectively), even though they surpassed the control by $2.38 \mathrm{~kg}$ representing + $15 \%$ heavier weight.

The highest $(P<0.05)$ lamb growth rate (Figure 2$)$, based on the duration between birth and weaning (i.e. 60 days), resulted from ewes given the low arginine at early pregnancy (EL; $224 \mathrm{~g} /$ head/day), however the lowest $(P<0.05)$ growth rate was found in lambs born of control ewes (166 g/head/day). Overall, there was no difference $(P>0.05)$ in the growth rate between lambs born of low (203 $\mathrm{g} /$ head/day) or high $(197 \mathrm{~g} /$ head/day) arginine-treated ewes. The best treatment (i.e. EL; the low arginine at early pregnancy) surpassed the control by $33 \%$ increase in the daily growth rate (Figure 2 ).

\subsection{Blood Metabolites in Pregnant Ewes}

As pregnancy advances, plasma protein (Figure 3) somewhat diminished in control ewes. Clearly, arginine at either level didn't raise blood plasma protein over control, yet rather it kept up the protein level at late pregnancy to its underlying level. The sole treatment that showed a reduced $(P<0.05)$ level of albumin was HE (Figure 3 ). Ewes given high arginine at their early pregnancy have shown the lowest albumin concentration ( $3.38 \mathrm{~g} / \mathrm{dl})$ being $25 \%$ less than in control $(4.73 \mathrm{~g} / \mathrm{dL})$. Whereas, other treatments exhibited a tendency $(P>0.05)$ of albumin reduction compared with control. There was a critical $(P<0.05)$ increment in globulins in ewe's given the low-dose of L-arginine at late pregnancy

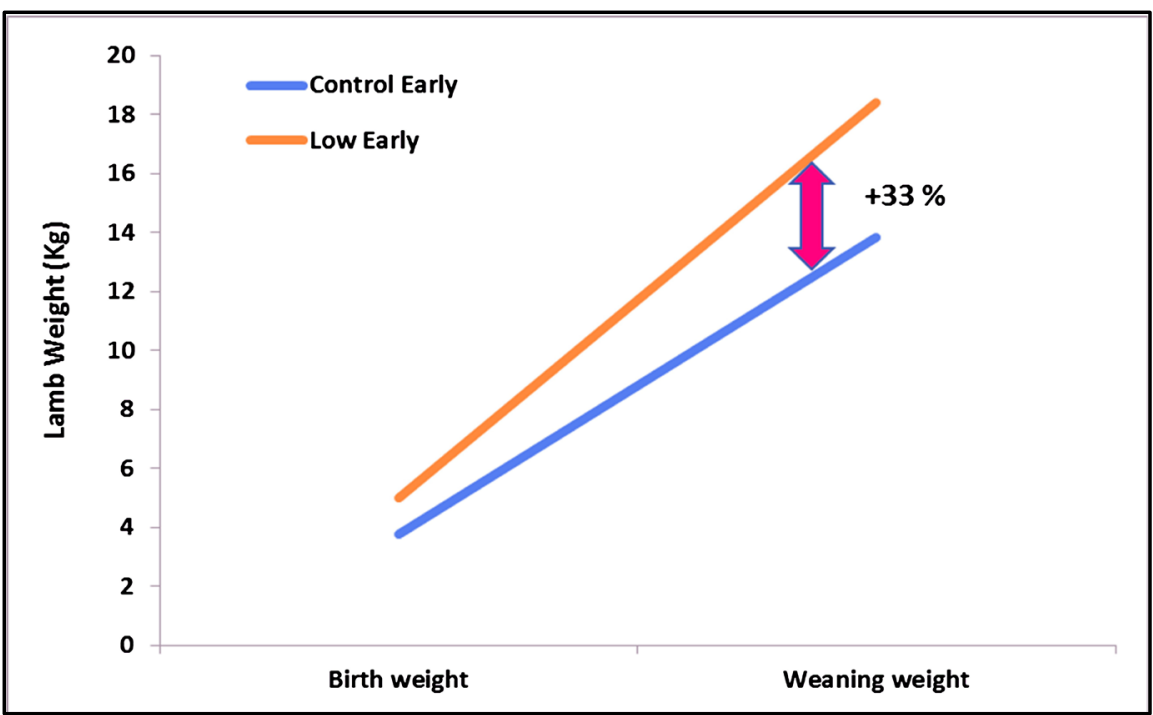

Figure 2. Comparison between growth rates in lambs born of Najdi ewes given low arginine at an early pregnancy relative to the early control lambs. 
(LL; $2.28 \mathrm{~g} / \mathrm{dl}$ ), representing $+54 \%$ above control (Figure 3 ). However other treatments (i.e. 1.61, 1.50 and $1.74 \mathrm{~g} / \mathrm{dl}$ in LE, $\mathrm{HE}$ and $\mathrm{HL}$, respectively) were not distinctive in globulins than control $(1.45 \mathrm{~g} / \mathrm{dL})$.

Generally, L-arginine diminished $(P<0.01)$ blood cholesterol compared with control (Figure 4). Percent of cholesterol reduction ranges between 5\% - 24\% of the corresponding control. Cholesterol levels were 57.95, 61.12, 47.33, 46.7, 50.4 and $57.83 \mathrm{mg} / \mathrm{dl}$ for CE, CL, LE, LL, HE and HL, respectively. Overall, stage of pregnancy didn't show a difference in blood cholesterol; however the limiting factor in cholesterol was the dose of L-arginine. The low arginine reduced $(P<$

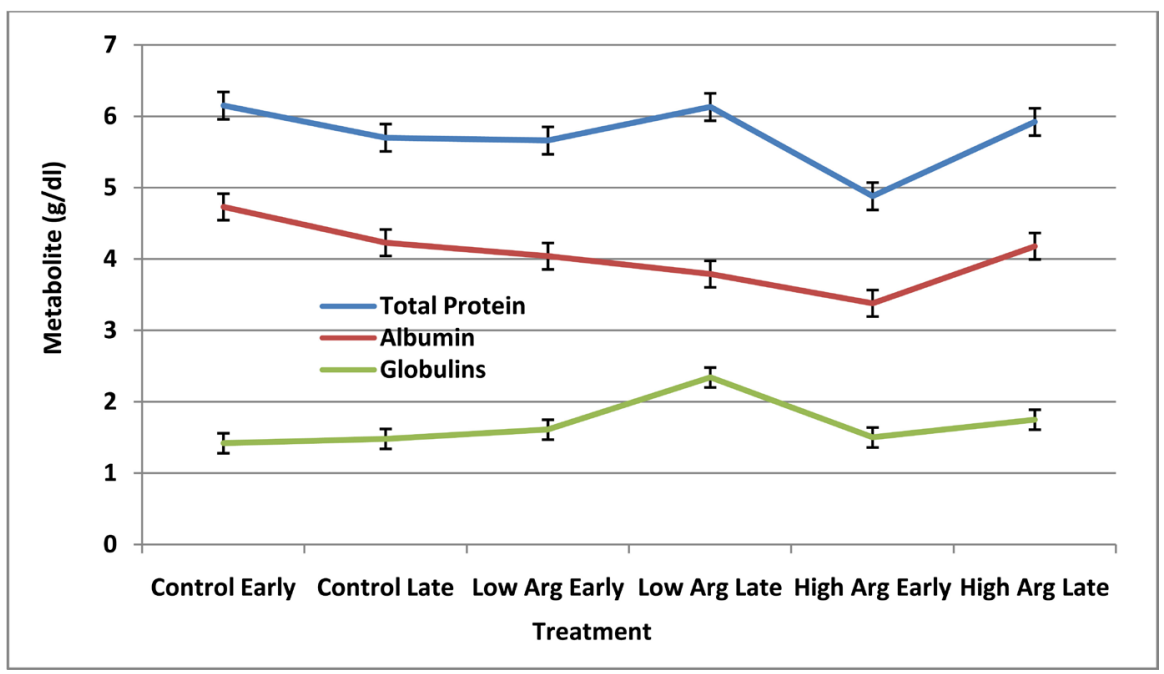

Figure 3. Effect of L-arginine dose $\times$ stage of pregnancy on plasma total protein, albumin and globulins in Najdi ewes. $(\mathrm{CE}=$ Saline at early pregnancy, $\mathrm{CL}=$ Saline at late pregnancy, $\mathrm{LE}=75 \mathrm{mg} / \mathrm{kg} \mathrm{BW}$ at early pregnancy, $\mathrm{LL}=75 \mathrm{mg} / \mathrm{Kg} \mathrm{BW}$ at late pregnancy, $\mathrm{HE}$ $=150 \mathrm{mg} / \mathrm{kg} \mathrm{BW}$ at early pregnancy, $\mathrm{HL}=150 \mathrm{mg} / \mathrm{kg} \mathrm{BW}$ at late pregnancy).

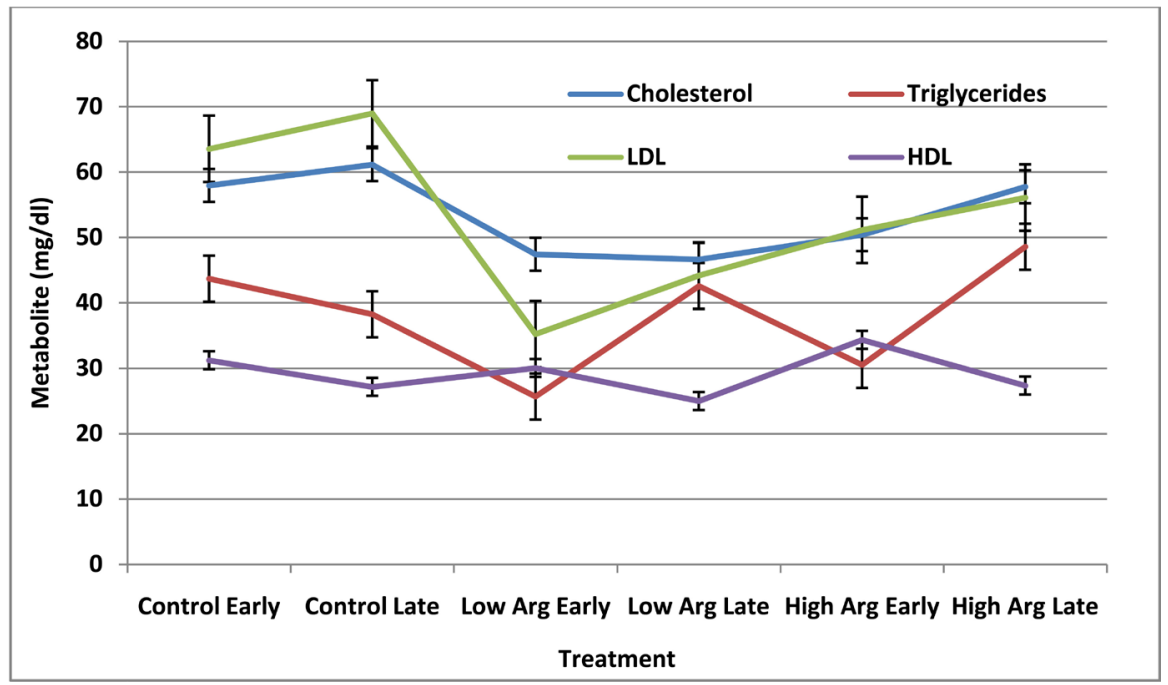

Figure 4. Effect of L-arginine dose $\times$ stage of pregnancy on plasma cholesterol, triglycerides, $\mathrm{LDL}$ and HDL in Najdi ewes. (CE = Saline at early pregnancy, $\mathrm{CL}=$ Saline at late pregnancy, $\mathrm{LE}=75 \mathrm{mg} / \mathrm{kg} \mathrm{BW}$ at early pregnancy, $\mathrm{LL}=75 \mathrm{mg} / \mathrm{kg} \mathrm{BW}$ at late pregnancy, $\mathrm{HE}=150 \mathrm{mg} / \mathrm{kg} \mathrm{BW}$ at early pregnancy, $\mathrm{HL}=150 \mathrm{mg} / \mathrm{kg} \mathrm{BW}$ at late pregnancy). 
0.05 ) blood cholesterol by $21 \%$ compared with control figures, however high arginine slightly $(P>0.05)$ reduced this value by barely $9 \%$. Administration of either dose of $\mathrm{L}$-arginine at early gestation reduced $(P<0.05)$ triglycerides $(\mathrm{TG})$ by $30 \%-41.5 \%$ of the control value (Figure 4 ). Contrariwise, giving L-arginine didn't change TG than control level, therefore the limiting factor for blood TG was pregnancy stage, not arginine dosage. Giving L-arginine at early gestation reduced $(P<0.05)$ TG $(25.54 \mathrm{mg} / \mathrm{dl})$ by $30 \%-41 \%$ of their control $(43.68$ $\mathrm{mg} / \mathrm{dL}$ ) counterparts. On the contrary, giving low L-arginine at late gestation slightly elevated TG $(42.6 \mathrm{mg} / \mathrm{dL})$ than its control $(38.25 \mathrm{mg} / \mathrm{dL})$ counterpart, while giving high $\mathrm{L}$-arginine at late gestation significantly $(P<0.05)$ elevated blood TG by $27 \%$ compared with its control counterpart. Plasma LDL levels were diminished $(P<0.01)$ as a result of giving L-arginine. The highest impact in LDL reduction was found in LE ewes $(35.23 \mathrm{~g} / \mathrm{dL})$ representing $45 \%$ below control value $(63.55 \mathrm{~g} / \mathrm{dL})$. Interaction $(P<0.01)$ between arginine dosage and stage of pregnancy was attained. The reduction values in LDL were $36 \%, 28 \%$ and 19\% in LL, HE and HL compared to control ewes (Figure 4). Plasma HDL profile (Figure 4) exhibited similar levels and trends in treatments as these found in control. The stage of pregnancy exhibited significant effect on plasma HDL level being higher at early $(31.83 \mathrm{~g} / \mathrm{dL})$ than at late pregnancy $(26.53 \mathrm{~g} / \mathrm{dL})$.

As shown in Figure 5, giving the high dose of L-arginine at either early (4.72 $\mathrm{g} / \mathrm{dL})$ or late $(4.07 \mathrm{~g} / \mathrm{dL})$ gestation significantly $(P<0.01)$ increased creatinine levels compared with control $(3.64 \mathrm{~g} / \mathrm{dL})$. Contrariwise, giving low L-arginine at early pregnancy didn't change $(3.86 \mathrm{~g} / \mathrm{dL})$ creatinine level than control or even significantly $(P<0.01)$ diminished creatinine when given at late pregnancy $(2.93$ $\mathrm{g} / \mathrm{dL})$. Overall, low arginine didn't change blood creatinine $(P>0.05)$, while high arginine elevated creatinine by $21 \%$ over the control value.

In the ordinary circumstances (i.e. control) urea profile (Figure 6) exhibited a significant $(P<0.01)$ decline at early $(62.07 \mathrm{~g} / \mathrm{dL})$ versus late $(75.03 \mathrm{~g} / \mathrm{dL})$ pregnancy.

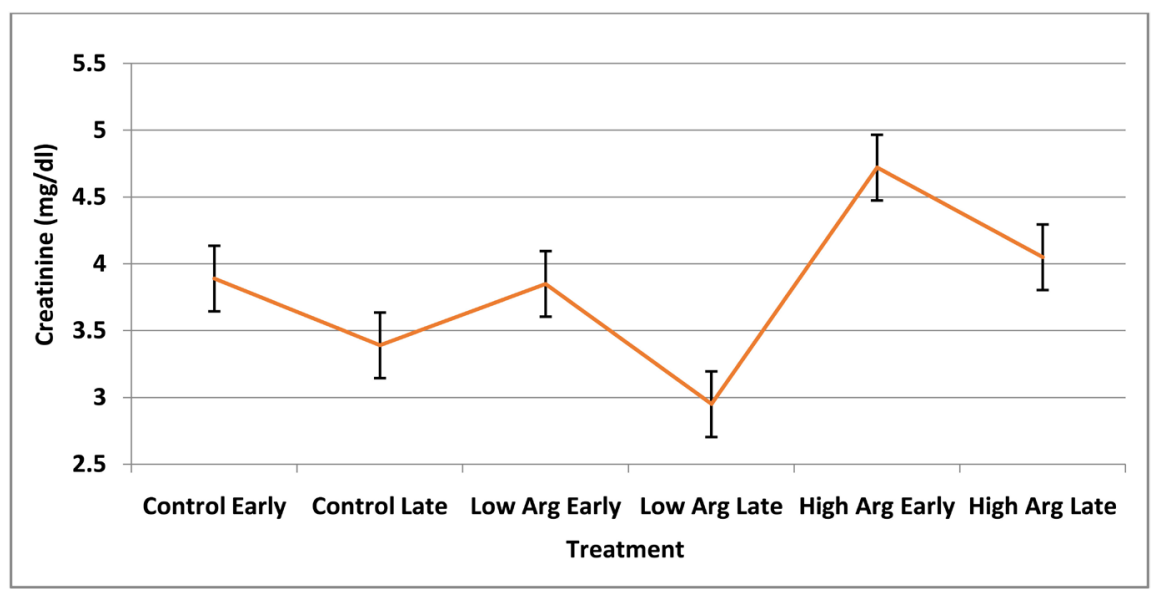

Figure 5. Effect of dosage of L-arginine $\times$ stage of pregnancy on plasma creatinine in Najdi ewes. (CE $=$ Saline at early pregnancy, $\mathrm{CL}=$ Saline at late pregnancy, $\mathrm{LE}=75 \mathrm{mg} / \mathrm{kg}$ $\mathrm{BW}$ at early pregnancy, $\mathrm{LL}=75 \mathrm{mg} / \mathrm{kg} \mathrm{BW}$ at late pregnancy, $\mathrm{HE}=150 \mathrm{mg} / \mathrm{kg} \mathrm{BW}$ at early pregnancy, $\mathrm{HL}=150 \mathrm{mg} / \mathrm{kg} \mathrm{BW}$ at late pregnancy). 
Administration of the high dose of L-arginine increased $(P<0.01)$ maternal blood urea at either stage by $13 \%$ - 19\%. Reversibly, giving the low dose (LE \&LL) of L-arginine not only maintained urea at its basic levels, but it also normalized the blood urea concentrations throughout pregnancy.

Administration of L-arginine significantly $(P<0.01)$ increased AST activity (Figure 7). Differences due stage of pregnancy were non-significant $(P>0.05)$. However, there were significant differences $(P<0.05)$ due to L-arginine dosage on AST. The increase of AST activity above the control reached 55\% in low and $70 \%$ in high dose-treated ewes. Concomitantly, ALT activity increased $(P<0.05)$ in all treatments, though the highest value was found in HL ewes (32.91 U/L) representing $38 \%$ above control. Low dosage of L-arginine optimizes the activity

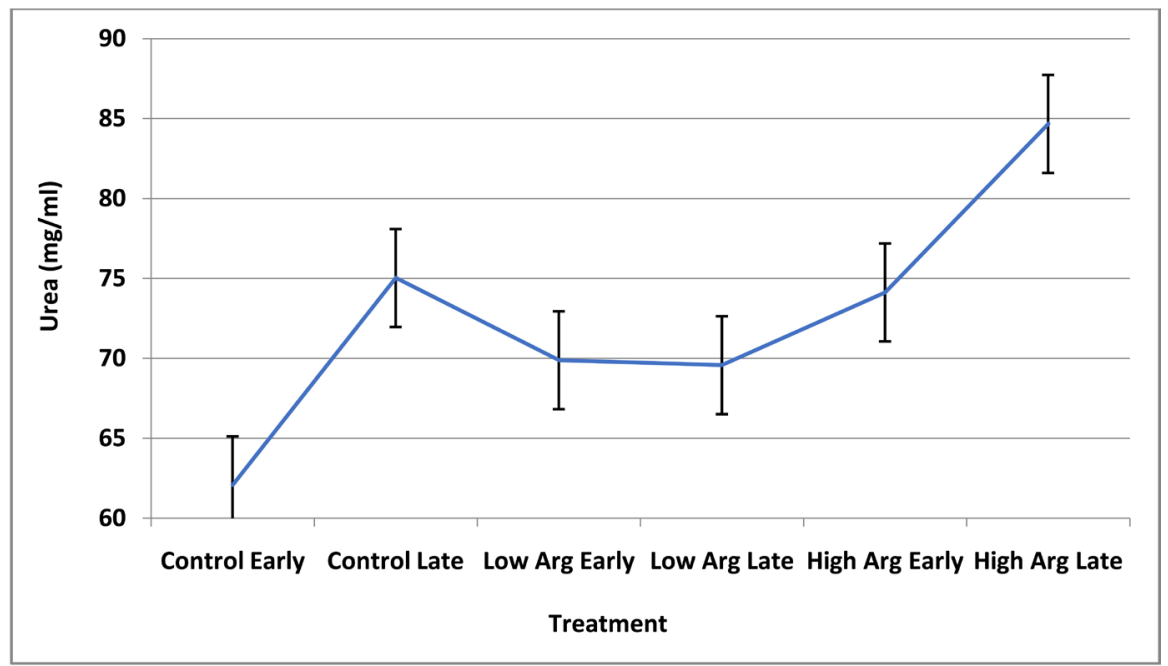

Figure 6. Effect of dosage of L-arginine $\times$ stage of pregnancy on plasma urea in Najdi ewes. $(\mathrm{CE}=$ Saline at early pregnancy, $\mathrm{CL}=$ Saline at late pregnancy, $\mathrm{LE}=75 \mathrm{mg} / \mathrm{kg} \mathrm{BW}$ at early pregnancy, $\mathrm{LL}=75 \mathrm{mg} / \mathrm{KG} \mathrm{BW}$ at late pregnancy, $\mathrm{HE}=150 \mathrm{mg} / \mathrm{kg} \mathrm{BW}$ at early pregnancy, $\mathrm{HL}=150 \mathrm{mg} / \mathrm{kg} \mathrm{BW}$ at late pregnancy).

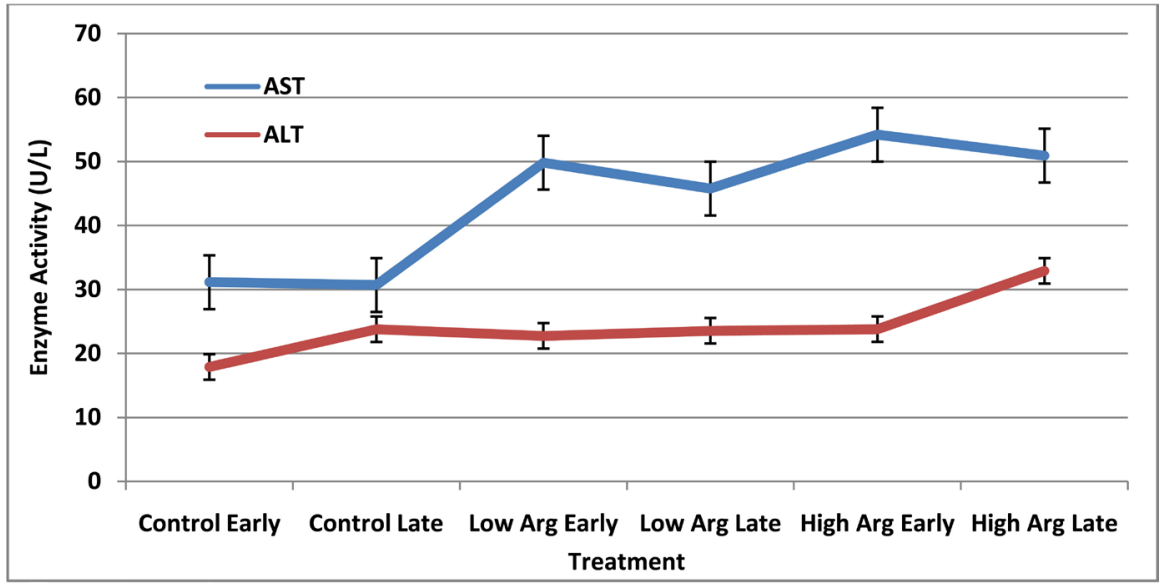

Figure 7. Effect of dosage of L-arginine $\times$ stage of pregnancy on plasma AST and ALT in Najdi ewes. $(\mathrm{CE}=$ Saline at early pregnancy, $\mathrm{CL}=$ Saline at late pregnancy, $\mathrm{LE}=75 \mathrm{mg} / \mathrm{kg}$ $\mathrm{BW}$ at early pregnancy, $\mathrm{LL}=75 \mathrm{mg} / \mathrm{kg} \mathrm{BW}$ at late pregnancy, $\mathrm{HE}=150 \mathrm{mg} / \mathrm{kg} \mathrm{BW}$ at early pregnancy, $\mathrm{HL}=150 \mathrm{mg} / \mathrm{kg} \mathrm{BW}$ at late pregnancy). 
of ALT throughout pregnancy (Figure 7).

\subsection{Milk Composition}

Table 1 presents data of milk analysis. Ewes given low arginine increased $(P<$ $0.05)$ total solids (TS), however ewes given high arginine slightly $(P>0.10)$ decreased milk TS. Likewise, low arginine maintained milk fat percent $(8.47 \%)$ compared with control $(8.29 \%)$, however high arginine decreased $(P<0.05)$ fat percent $(7.03 \%)$. There were slight $(P=0.06)$ increases in protein due to treatment. Solids nonfat (SNF) was higher in LE, LL and HL than in CE. Percent of milk lactose was not different in LE, LL and HE than in CL. However, milk ash was higher $(P<0.05)$ in high than in low-arginine or control ewes.

\section{Discussion}

The increase in birth weight in the treated ewes might be ascribed to the anabolic effects of $\mathrm{L}$ arginine due to its angiogenic effect on the placental blood vessels. The low dosage of arginine given at early gestation resulted in the best birth $(4.99 \mathrm{~kg})$ and weaning $(18.4 \mathrm{~kg})$ weights. During early days of pregnancy the mothers require protein as a signal for the maternal recognition of pregnancy [11]. Moreover, survival rates at birth and weaning were $100 \%$ in the low dose-early pregnancy ewe's offspring. The high ambient temperature in which these animals were raised represents a challenge at the early implantation. This was alleviated by the supplementation of L-arginine at this early period. The susceptibility of the sheep fetus to the heat stress declines by the progress of pregnancy [24]. Evidently, intrauterine growth restriction (IUGR) has long been known as a common reproductive drawback causing pulmonary atresia in sheep fetuses [25]. However, supplementary L-arginine in the diets of mammals had shown beneficial functions on the fetal growth and development due to its activation of nitrous oxide (NO) and polyamines [26]. The less effectiveness of the high dose of L-arginine on the neonatal birth weights or the survival rates at birth in the current study might be attributed mainly to the edematic effects of

Table 1. Effect of dose of L-arginine $\times$ stage of pregnancy on postpartum milk composition in Najdi ewes.

\begin{tabular}{|c|c|c|c|c|c|c|}
\hline \multirow{2}{*}{ Milk constituent $\%$} & \multicolumn{6}{|c|}{ Treatment } \\
\hline & Control Early & Control Late & Low Arg. Early & Low Arg. Late & High Arg. Early & High Arg. Late \\
\hline Moisture & $85.21 \pm 1.11^{\mathrm{a}^{*}}$ & $81.44 \pm 0.67^{\mathrm{c}}$ & $81.82 \pm 1.26^{\mathrm{bc}}$ & $82.24 \pm 1.20^{\mathrm{bc}}$ & $84.59 \pm 0.61^{\mathrm{ab}}$ & $83.06 \pm 0.56^{\mathrm{abc}}$ \\
\hline Total Solids & $14.81 \pm 1.11^{\mathrm{c}}$ & $18.56 \pm 0.67^{\mathrm{a}}$ & $18.18 \pm 1.26^{\mathrm{ab}}$ & $17.76 \pm 1.20^{\mathrm{ab}}$ & $15.41 \pm 0.61^{\mathrm{bc}}$ & $16.94 \pm 0.56^{\mathrm{abc}}$ \\
\hline Fat & $7.27 \pm 0.65^{\mathrm{bc}}$ & $9.30 \pm 0.62^{\mathrm{a}}$ & $9.11 \pm 0.84^{\mathrm{ab}}$ & $7.83 \pm 0.66^{\mathrm{abc}}$ & $6.55 \pm 0.28^{c}$ & $7.51 \pm 0.40^{\mathrm{abc}}$ \\
\hline Lactose & $2.70 \pm 0.44^{\mathrm{b}}$ & $3.97 \pm 0.35^{\mathrm{a}}$ & $3.53 \pm 0.28^{\mathrm{ab}}$ & $3.98 \pm 0.37^{\mathrm{a}}$ & $2.80 \pm 0.27^{\mathrm{b}}$ & $4.24 \pm 0.22^{\mathrm{a}}$ \\
\hline Protein & $3.99 \pm 0.20^{\mathrm{b}}$ & $4.50 \pm 0.35^{\mathrm{a}}$ & $4.73 \pm 0.45^{\mathrm{a}}$ & $5.08 \pm 0.37^{\mathrm{a}}$ & $5.11 \pm 0.41^{\mathrm{a}}$ & $4.27 \pm 0.36^{\mathrm{ab}}$ \\
\hline Ash & $0.84 \pm 0.03^{c d}$ & $0.79 \pm 0.02^{\mathrm{d}}$ & $0.81 \pm 0.03^{\mathrm{cd}}$ & $0.87 \pm 0.02^{\mathrm{bc}}$ & $0.94 \pm 0.02^{\mathrm{a}}$ & $0.92 \pm 0.01^{\mathrm{ab}}$ \\
\hline
\end{tabular}

${ }^{* a, b, c, d}$ Means in the same row with different superscripts significantly $(P<0.05)$ differ. $\mathrm{CE}=$ Saline at early pregnancy, CL $=$ Saline at late pregnancy, LE $=75$ $\mathrm{mg} / \mathrm{kg} \mathrm{BW}$ at early pregnancy, $\mathrm{LL}=75 \mathrm{mg} / \mathrm{kg} \mathrm{BW}$ at late pregnancy, $\mathrm{HE}=150 \mathrm{mg} / \mathrm{kg} \mathrm{BW}$ at early pregnancy, $\mathrm{HL}=150 \mathrm{mg} / \mathrm{kg} \mathrm{BW}$ at late pregnancy. 
such a dose on the maternal tissues and its udder.

The congested teats impeded the natural suckling of the neonates resulting in a high percent of mortality. Overall, the best treatment in milk yield (visual observation, not determined) and composition was found in LE-ewes resulting in the heaviest lamb weaning weights. Arginine serves as a common precursor for the synthesis of NO (a vasodilator and a signaling molecule) and polyamines (key regulators of DNA and protein synthesis) that are crucial for placental angiogenesis and growth in mammals [27] [28] [29] [30]. Moreover, Saevre et al. also found that during the early stages of embryogenesis, the supplemental arginine could have rescued weaker embryos entering the early stages of regression through its role on nitric oxide and polyamine synthesis [31]. Polyamines and nitric oxide may have directly enhanced embryonic cellular proliferation and differentiation to ensure and promote embryonic survival [32].

The lowering effect of L-arginine on blood lipid fractions, in the current study agrees with a previous study [6]. Likewise, declines in plasma protein and albumin as a consequence to $\mathrm{L}$ arginine supplementation were found in pigs [33]. It is previously mentioned that supplementation with L-arginine enhances immunoglobulin's production [34]. The elevation of creatinine and urea in the high arginine-supplemented ewes would unravel the edema found in these groups which burdened the postnatal maternity and the ability of neonates for normal suckling. In a study on rats, to investigate the effects of acute versus chronic supplementation of L-arginine on renal ischemia, there found deleterious effects due to the chronic, but not acute treatment on the renal function. The chronic supplementation of L-arginine increased blood urea causing partial damage to the nephrons [35]. This finding was supported by Ingram et al. who documented that the reduced early cell proliferation in the glomerulus following two weeks supplementation with $\mathrm{L}$ arginine is mediated, in part, by the attenuation of local endothelin-1 (ET-1) production which is further supported by the observation that treatment of uremic animals with a NO donor reduced ET-1 excretion [36]. The main biomarkers of the integrity of the hepatic cells are AST and ALT. In the current study, giving arginine significantly increased AST at all tested levels, however the sole increase in ALT was found in ewes given high arginine at late gestation. The increases of AST and ALT were observed in rabbits given L-arginine [37]. In spite of such increases of the activity of hepatic enzymes, it looks understandable that these tested doses of L-arginine are still within the physiological accepted levels. This suggestion would be reasonable with the fact that both doses of L-arginine at either stage of gestation resulted in higher, or even similar, neonatal birth weight and comparable survival. Milk production is influenced by the angiogenesis of mammary tissue and blood flow to mammary glands, which enhance nutrient delivery to the mammary gland for milk synthesis [38]. Mammary gland blood flow and angiogenesis are regulated by arginine-derived nitric oxide [39]. Furthermore, milk production is highly correlated with mammary gland growth and arginine is required for optimal mam- 
mary gland growth [40]. The increase of insulin release in the ewes given arginine would also explain the higher metabolic turnover in mammary cells [11].

\section{Conclusion}

The dosage and duration of administration of L-arginine must be considered when designing an experiment to test its effect on cell biology. Moreover, type of animals (i.e. monogastrics vs. ruminants) is of great concern with respect of timing and duration of administration. Drenching pregnant ewes at their early ( first 60 days post breeding) gestation with a daily dose of $75 \mathrm{mg} \mathrm{L}$-arginine per kilogram body weight would be a beneficial approach to obtain heavy and healthy offspring and maintain the maternal health wellbeing. Moreover, this study must be furthered by using larger numbers of animals and also to quantitate the milk yield and its chemical composition and correlate such traits with neonatal survival and growth.

\section{Acknowledgements}

The authors acknowledge Qassim University for providing the lodging for animals, and the farm crew for their assistance throughout the experiment.

\section{Compliance with Ethical Standards}

This study was approved by the Animal Care and Welfare Committee, Deanship of Scientific Research, Qassim University, Kingdom of Saudi Arabia.

\section{Conflicts of Interest}

The authors declare no conflicts of interest regarding the publication of this paper.

\section{References}

[1] Wu, G. (2014) Dietary Requirements of Synthesizable Amino Acids by Animals: A Paradigm Shift in Protein Nutrition. Journal of Animal Science and Biotechnology, 5, 34-45. https://doi.org/10.1186/2049-1891-5-34

[2] Wu, G., Bazer, F.W., Davis, T.A., Kim, S.W., Li, P., Rhoads, J.M., Satterfield, M.C., Smith, S.B., Spencer, T.E. and Yin, Y.L. (2009) Arginine Metabolism and Nutrition in Growth, Health and Disease. Amino Acids, 37, 153-168. https://doi.org/10.1007/s00726-008-0210-y

[3] Alderton, W.K., Cooper, C.E. and Knowles, R.G. (2001) Nitric Oxide Synthases: Structure, Function and Inhibition. Biochemistry Journal, 357, 593-615. https://doi.org/10.1042/bj3570593

[4] Martin, E.A., Nicholson, W.T., Eisenach, J.H., Charkoudian, N. and Joyner, M.J. (2006) Influences of Adenosine Receptor Antagonism on Vasodilator Responses to Adenosine and Exercise in Adenosine Responders and Non-Responders. Journal of Applied Physiology, 101, 1678-1684. https://doi.org/10.1152/japplphysiol.00546.2006

[5] Ignarro, L.J., Cirino, G., Casini, A. and Napoli, C. (1999) Nitric Oxide as a Signaling Molecule in the Vascular System: An Overview. Journal of Cardiovascular Pharma- 
cology, 34, 879-886. https://doi.org/10.1097/00005344-199912000-00016

[6] Wu, Z., Satterfield, M.C., Bazer, F.W. and Wu, G. (2012) Regulation of Brown Adipose Tissue Development and White Fat Reduction by L-Arginine. Current Opinion in Clinical Nutrition \& Metabolic Care, 6, 529-538.

https://doi.org/10.1097/MCO.0b013e3283595cff

[7] Wu, G., Bazer, F.W., Datta, S., Gao, H., Johnson, G.A., Lassala, A., Li, P., Satterfield, M.C. and Spencer, T.E. (2008) Intrauterine Growth Retardation in Livestock: Implications, Mechanisms and Solutions. Archive of Animal Breeding, 1, 4-10.

[8] Zeng, X.F., Wang, F.L., Fan, X., Yang, W., Zhou, B., Li, P., Yin, Y., Wu, G. and Wang, J. (2008) Dietary Arginine Supplementation during Early Pregnancy Enhances Embryonic Survival in Rats. Journal of Nutrition, 138, 1421-1425.

https://doi.org/10.1093/jn/138.8.1421

[9] Lassala, A., Bazer, F.W., Cudd, T.A., Datta, S., Keisler, D.H., Satterfield, M.C., Spencer, T.E. and Wu, G. (2011) Parenteral Administration of L-Arginine Enhances Fetal Survival and Growth in Sheep Carrying Multiple Fetuses. Journal of Nutrition, 141, 849-855. https://doi.org/10.3945/jn.111.138172

[10] Mateo, R.D., Wu, G., Bazer, F.W., Park, J.C., Shinzato, I. and Kim, S.W. (2007) Dietary L-Arginine Supplementation Enhances the Reproductive Performance of Gilts. Journal of Nutrition, 137, 652-656. https://doi.org/10.1093/jn/137.3.652

[11] Zeitoun, M.M., Al-Ghoneim, A.A., Al-Sobayil, K.A. and Al-Dobaib, S.N. (2016) L-Arginine Modulates Maternal Hormonal Profiles and Neonatal Traits during Two Stages of Pregnancy in Sheep. Open Journal of Animal Sciences, 6, 95-104.

https://doi.org/10.4236/ojas.2016.62012

[12] National Research Council of the National Academies (NRC) (1985) Nutrients Requirements of Sheep. National Research Council, Roma, Sixth Rev. Ed., 112.

[13] Weichselbaum, T.E. (1946) An Accurate and Rapid Method for the Determination of Proteins in Small Amounts of Blood Serum and Plasma. American Journal of Clinical Pathology, 16, 40-48. https://doi.org/10.1093/ajcp/16.3_ts.40

[14] Doumas, B.T., Watson, W. and Biggs, H.G. (1971) Albumin Standards and the Measurement of Serum Albumin with Bromcresol Green. Clinica Chimica Acta, 31, 87-96. https://doi.org/10.1016/0009-8981(71)90365-2

[15] Seftel, H.C., Panz, V.R., Baker, S.G., Joffe, B.I. and Mendelsohn, D. (1988) Determination of Cholesterol and Triglycerides in Blood: A Comparison between Wet Chemistry Methods and a Dry Chemistry Analyzer. Annals of Clinical Biochemistry, 25, 176-180. https://doi.org/10.1177/000456328802500208

[16] Okada, M., Matsui, H., Ito, Y., Fujiwara, A. and Inano, K. (1998) Low-Density Lipoprotein Cholesterol Can Be Chemically Measured: A New Superior Method. Journal of Laboratory and Clinical Medicine, 132, 195-201. https://doi.org/10.1016/S0022-2143(98)90168-8

[17] Gordon, T., Castelli, W.P., Hjortland, M.C., Kannel, W.B. and Dawber, T.R. (1977) High Density Lipoprotein as a Protective Factor against Coronary Heart Disease. The Framingham Study. American Journal of Medicine, 62, 707-714. https://doi.org/10.1016/0002-9343(77)90874-9

[18] Bartels, H. and Boehmer, M. (1971) Micro Determination of Creatinine. Clinica Chimica Acta, 32, 81-85. https://doi.org/10.1016/0009-8981(71)90467-0

[19] Fawcett, J.K. and Scott, J.E. (1960) A Rapid and Precise Method for the Determination of Urea. Journal of Clinical Pathology, 13, 156-159.

https://doi.org/10.1136/jcp.13.2.156

[20] Thefeld, W., Hoffmeister, H., Busch, E.W., Koller, P.U. and Vollmar, J. (1974) Re- 
ferenzwerte für die bestimmungen der transaminasen GOT und GPT sowie der alkalischen phosphatase im serum mit optimierten standard methoden. Deutsch $\mathrm{Me}$ dizinsche Wochenschrif, 99, 343-351. https://doi.org/10.1055/s-0028-1107760

[21] Association of Official Analytical Chemist, AOAC (2000) Official Methods of Analysis of the Association of Official Analytical Chemist. 16th Edition, Gaithersburg, 1-24.

[22] SAS (2000) Statistical Analysis System User's Guide. Version 8, SAS Institute, Cary.

[23] Steel, R.G.D. and Torrie, J.H. (1997) Principles and Procedures of Statistics: A Biometrical Approach. 3rd Edition, McGraw-Hill, New York.

[24] Hansen, P.J. (2009) Effects of Heat Stress on Mammalian Reproduction. Philosophical Transactions of the Royal Society London B: Biological Science, 364, 3341-3350. https://doi.org/10.1098/rstb.2009.0131

[25] Orgeig, S., Crittenden, T.A., Marchant, C., McMillan, I.C. and Morrison, J.L. (2010) Intrauterine Growth Restriction Delays Surfactant Protein Maturation in the Sheep Fetus. American Journal of Physiology of Lung Cell and Molecular Physiology, 298, L575-L583. https://doi.org/10.1152/ajplung.00226.2009

[26] Wu, G., Bazer, F.W., Satterfield, M.C., Li, X., Wang, X., Johnson, G.A., Burghardt, R.C., Dai, Z., Wang, J. and Wu, Z. (2013) Impacts of Arginine Nutrition on Embryonic and Fetal Development in Mammals. Amino Acids, 45, 241-256.

https://doi.org/10.1007/s00726-013-1515-z

[27] Wu, G., Pond, W.G., Flynn, S.P., Ott, T.L. and Bazer, F.W. (1998) Maternal Dietary Protein Deficiency Decreases Nitric Oxide Synthase and Ornithine Decarboxylase Activities in Placenta and Endometrium of Pigs during Early Gestation. Journal of Nutrition, 128, 395-402. https://doi.org/10.1093/jn/128.12.2395

[28] Sheppard, C., Shaw, C.E., Li, Y., Bird, I.M. and Magness, R.R. (2001) Endothelium-Derived Nitric Oxide Synthase Protein Expression in Ovine Placental Arteries. Biology of Reproduction, 64, 1494-1499. https://doi.org/10.1095/biolreprod64.5.1494

[29] Wu, G., Bazer, F.W. and Davis, T.A. (2007) Important Roles for the Arginine Family of Amino Acids in Swine Nutrition and Production. Livestock Science, 112, 8-22. https://doi.org/10.1016/j.livsci.2007.07.003

[30] Huang, L.T., Hsieh, C.S., Chang, K.A. and Tain, Y.L. (2012) Roles of Nitric Oxide and Asymmetric Dimethyl Arginine in Pregnancy and Fetal Programming. International Journal of Molecular Science, 13, 14606-14622.

https://doi.org/10.3390/ijms131114606

[31] Saevre, C.B., Caton, J.S., Luther, J.S., Meyer, A.M., Dhuyetter, D.V., Musser, R.E., Kirsch, J.D., Kapphahn, M., Redmer, D.A. and Schauer, C.S. (2011) Effects of Rumen Protected Arginine Supplementation on Ewe Serum Amino Acid Concentration, Circulating Progesterone and Ovarian Blood Flow. Sheep and Goat Research Journal, 26, 8-12.

[32] Saevre, C.B., Meyer, A.M., Van Emon, M.L., Redmer, D.A., Caton, J.S., Kirsch, J.D., Luther, J.S. and Schauer, C.S. (2011) Impacts of Arginine on Ovarian Function and Reproductive Performance at the Time of Maternal Recognition of Pregnancy in Ewes. Sheep Research Report, 52, 13-16.

[33] He, Q., Kong, X., Wu, G., Ren, P., Tang, H., Hao, F., Huang, R., Li, T., Tan, B., Li, P., Tang, Z., Yin, Y. and Wu, Y. (2009) Metabolomics Analysis of the Response of Growing Pigs to Dietary L-Arginine Supplementation. Amino Acids, 37, 199-208. https://doi.org/10.1007/s00726-008-0192-9

[34] Nieves, C. and Langkamp-Henken, B. (2002) Arginine and Immunity: A Unique 
Perspective. Biomedicine Pharmacotherapy, 56, 471-482.

https://doi.org/10.1016/S0753-3322(02)00291-3

[35] Tomé, L.A., Yu, L., de Castro, I., Campos, S.B. and Seguro, A.C. (1999) Beneficial and Harmful Effects of L-Arginine on Renal Ischemia. Nephrology Dialysis Transplantation, 14, 1139-1145. https://doi.org/10.1093/ndt/14.5.1139

[36] Ingram, A., Parbtani, A., Thai, K., Ly, H., Shankland, S.J., Morrissey, G. and Scholey, J.W. (1995) Dietary Supplementation with L-Arginine Limits Cell Proliferation in the Remnant Glomerulus. Kidney International, 48, 1857-1865. https://doi.org/10.1038/ki.1995.484

[37] Taha, M.O., Simões, M.J., Haddad, M.A., Capelato, R.C., Budny, N., Matsumoto, A.H., Soares, P.C.M., Santos, W.M., Armeato, G.D., Araki, C.M., Gomes, J.S.M., Magalhães, K.G., Tersariol, I.L.S., Monteiro, H.P., Oliveira, I., Jurkiewicz, A. and Caricati-Neto, A. (2009) L-Arginine Supplementation Protects against Hepatic Ischemia Reperfusion Lesions in Rabbits. Transplantation Proceedings, 41, 816-819. https://doi.org/10.1016/j.transproceed.2009.02.050

[38] Trottier, N.L., Shipley, C.F. and Easter, R.A. (1997) Plasma Amino Acid Uptake by the Mammary Gland of the Lactating Sow. Journal of Animal Science, 75, 1266-1278. https://doi.org/10.2527/1997.7551266x

[39] Lacasse, P. and Prosser, C.G. (2003) Mammary Blood Flow Does Not Limit Milk Yield in Lactating Goats. Journal of Dairy Science, 86, 2094-2097. https://doi.org/10.3168/jds.S0022-0302(03)73798-9

[40] Pau, M.Y. and Milner, J.A. (1982) Effect of Arginine Deficiency on Mammary Gland Development in the Rat. Journal of Nutrition, 112, 1827-1833.

https://doi.org/10.1093/jn/112.10.1827 